\title{
Ser du gorillaen i rommet? Om å undervise i observasjon ved bruk av fiksjonalisering
}

\author{
Jannike Ohrem Bakke og Fride Lindstøl`1 \\ Universitetet $i$ Sørøst-Norge, Norge
}

\begin{abstract}
Sammendrag
I denne dramaturgiske studien undersøker vi hvordan lærerstudenter trener på observasjon som ferdighet og metode for å forberede seg til observasjonspraksis i skolen. Treningen foregår i et profesjonsverksted, en arena for undervisning og forskning. Ved hjelp av nasjonale og lokale styringsdokumenter for lærerutdanningen, GLU, samt pensumlitteratur om observasjon, identifiserer vi konkrete observasjonsferdigheter og utforsker hvordan dette kan omsettes til praktisk undervisning. Undervisningen er sentrert rundt ulike former for fiksjonalisering, som i denne konteksten betyr hvordan lærerutdannere bruker rom, kropp, tid og tekst til å iscenesette tenkte hendelser fra skole og klasserom. Vi bruker dramaturgiske analyser for å undersøke undervisningsforløp og hendelser som handler om å observere. Studien viser hvordan fiksjonalisering kan anvendes for å trene på spesifikke ferdigheter som å sanse og tolke, som inngår i det å observere. Vi identifiserer også måter å komponere undervisning på som kan bidra til å innvie studentene i observasjon som metode.
\end{abstract}

Nøkkelord: dramaturgisk analyse; fiksjonalisering; å undervise om à undervise; profesjonsverksted; observasjonspraksis

Received: October, 2020; Accepted: April, 2021; Published: June, 2021

\begin{abstract}
Do you see the gorilla? Teaching observation by fictionalization

This dramaturgical study is an investigation of how teacher students train observation skills and methods in preparation for observational practice in school. This training takes place in a professional workshop, an arena for teaching and research. Using national and local management documents, as well as syllabus literature about observation, we identify specific observation skills and examine how these can be translated into classroom practice. Teaching is focused on various forms of fictionalization, which in this context refers to how teacher educators use space, the body, time and text to stage imagined events from the school and the classroom. The study shows how fictionalization can be used to train specific skills, such as sensory and interpretive ones, that are
\end{abstract}

${ }^{1}$ Bakke og Lindstøl er likeverdige forfattere av artikkelen.

^Korrespondanse: Fride Lindstøl, e-post: fride.1.hansen@usn.no

(C) 2021 J. O. Bakke \& F. Lindstøl. This is an Open Access article distributed under the terms of the Creative Commons Attribution 4.0 International License (https://creativecommons.org/licenses/by-nc/4.0/), allowing third parties to copy and redistribute the material in any medium or format and to remix, transform, and build upon the material for any purpose, even commercially, provided the original work is properly cited and states its license.

Citation: F. O. Bakke E F. Lindstol. «Ser du gorillaen i rommet? Om à undervise i observasjon ved bruk av fiksjonalisering». Fournal for Research in Arts and Sports Education, Special issue: Dramaturgiske perspektiver på didaktiske kontekster, Vol. 5(2), 2021, 


\section{F. O. Bakke \&o F. Lindstøl}

needed for classroom observation. We also identify ways of composing teaching that can help to familiarize students with observation method.

Keywords: dramaturgical analysis; fictionalization; teaching about teaching; learning lab

Innenfor kognitiv vitenskap har man gjentatte ganger utført følgende eksperiment med samme resultat: Publikum blir bedt om å se en film av to lag som spiller basketball. Noen i publikum får i oppdrag å telle antall ganger ballen skifter hender. Midt under kampen kommer en mann med gorillakostyme inn på banen. Han snur seg mot kamera, dunker seg på brystet og går ut igjen. Halvparten av betrakterne ser ikke gorillaen. De nekter å tro at han var der - inntil filmen spilles en gang til. Da får de faktisk øye på apen som rusler inn og ut av banen. Resten av publikum får ingen oppdrag. Likevel ser de stort sett gorillaen. Dette eksperimentet illustrerer hvordan menneskers erfaring, forventning og kunnskap virker inn på blikket, hva vi ser, og hvordan vi observerer verden (Hustvedt, 2013, s. 275). Det tydeliggiør et skille mellom å betrakte og å se: «Når vi betrakter uten å se, handler det stort sett om manglende innsikt, at vi mangler evnen til å gjette betydningen av noe i verden omkring oss» (Hustvedt, 2013, s. 275).

Når lærerstudenter observerer i klasserommet, tar de også gjerne i bruk fortellinger og erfaringer fra egne elevroller og skoleerfaringer (Germeten \& Bakke, 2013, s. 110; Østrem, 2009, s. 372). De bruker sine hverdagserfaringer fordi de ikke har trent opp et profesjonelt lærerblikk. Erfaringene virker inn på $h v a$ de ser og hvordan de tolker observasjonene. Men observasjonene kan, som gorillaeksperimentet viste, være feilinformasjon. Det å lære seg å observere bygger på en erkjennelse av at menneskelige svakheter kan bidra til at vi ofte både oppfatter og tolker feil (Gjøsund \& Huseby, 2017, s. 12). For å utvikle en profesjonell praksis og rolle behøver derfor lærerstudentene både undervisning og trening $\mathrm{i}$ observasjon.

I flere studier argumenteres det for at lærerstudenter trenger å trene på praktiske ferdigheter for å bli bedre rustet til å utvikle og utforske muligheter som kan oppstå i undervisningsrommet (Grossman et al., 2009, s. 277-278; Janssen et al., 2015, s. 139-144; Jenset et al., 2018). I studier av lærerutdanneres undervisning blir praktisk trening ofte forklart som a simulere, det vil si at studentene imiterer eller gjenskaper situasjoner, roller eller hendelsesforløp fra klasserommet (Darling-Hammond, 2006a, s. 308; Dotger, 2011; Jong et al., 2012, s. 36). Undervisning i observasjon har ofte dreid seg om å studere manualer eller skjema til bruk i ordinær praksis. I denne studien ønsker vi å utforske og utvikle praktisk trening i observasjon gjennom å eksperimentere med ulike former for fiksjonalisering. I dramaturgiske kontekster handler fiksjonalisering om hvordan man kan forstille seg, iscenesette, uttrykke noe eller noen som kunne ha vært eller kommer til å bli (Gladsø et al., 2005, s. 182). Fiksjonalisering skjer giennom den som gir form til fantasien, men fullføres av den som «mottar» fiksjonen (Gladsø et al., 2005, s. 183). I didaktiske kontekster er fiksjonalitet en egenskap ved kommunikasjon som både lærere og elever kan uttrykke eller oppfatte, ofte for å erkjenne og lære. Fiksjonalisering fungerer som et signal om 
at virkeligheten ikke framstilles som den er, men er formgitt og mediert (Knudsen \& Krøgolt, 2019, s. 38). I denne studien utforskes ulike fiksjonaliseringsformer for å utvikle et bredere metodisk repertoar knyttet til undervisning generelt og observasjon spesielt. Vi spør: Hvordan kan fiksjonalisering brukes til å trene på à observere $i$ lererutdanningen?

\section{Undervisning i observasjon}

I nasjonale styringsdokumenter for grunnskolelærerutdanningen, GLU, er observasjon beskrevet både som ferdighet og metode. Det brukes formuleringer som «ha et blikk for alle elevene» og «å kunne innta et forskerblikk» (Kunnskapsdepartementet, 2016a, 2016b). Studentene skal innvies i "observasjon og analyse ved starten av studiet til det å kunne innta forskerblikk og videreutvikle forsknings- og erfaringsbaserte undervisningspraksiser $\mathrm{i}$ den siste delen av studiet» (Kunnskapsdepartementet, 2016a, \ 3.8). I nasjonal og lokal emneplan for pedagogikk presiseres det at «Studentene kan planlegge og gjennomføre systematisk observasjon og analysere data” (Nasjonalt råd for lærerutdanning, 2017a, s. 20, 2017b, s.19; USN, 2018a, 2018b). I lokale emneplaner for praksis står det at «studentene skal observere når praksislærer og medstudenter underviser» (USN, 2019, s. 5). Kort oppsummert kan man si at styringsdokumentene framhever flere sider ved observasjon både som ferdighet og metode, men at det er opp til lærerutdannere å omsette dette til praktisk undervisning.

For å identifisere og konkretisere observasjon som metode og ferdighet, har vi studert faglitteratur som benyttes i pedagogikkemnet på GLU ved USN (jf. Bjørndal, 2012; Germeten \& Bakke, 2013; Gjøsund \& Huseby, 2017; Postholm \& Jacobsen, 2011). I disse fagtekstene kobles observasjon som ferdighet til ulike faser i en prosess «fra sansing, via nedtegning og nedskriving, til fortolkning, forklaring, og forståelse av det vi tror vi har sett» (Germeten \& Bakke, 2013, s. 110). Det er tre ferdigheter som beskrives som sentrale for observasjon i klasserommet i disse kildene: sansetrening, tolketrening og observasjon som metode.

Sansetrening. Når lærere observerer, tar de i bruk flere sanser: syn, hørsel, følelse, lukt og smak (Bjørndal, 2012, s. 33; Postholm \& Jacobsen, 2011, s. 49). Sansing kan gi observatøren tilgang til informasjon om kvaliteter, aktiviteter, handlinger og relasjoner mellom elever og lærere (Germeten \& Bakke, 2013, s. 110). Under sansingen foregår ulike former for seleksjon: «Når vi observerer, er det bare et utvalg av det vi sanser, som vi tar hensyn til» (Gjøsund \& Huseby, 2017, s. 25-26). Både observasjonsrollen og oppgaven spiller inn på hva vi legger merke til og hva som blokkeres ut. Studenter bør trene på å bruke sanser for å innhente informasjon og bli bevisst på en indirekte utskillende sanse- eller persepsjonsopplevelse (Germeten \& Bakke, 2013, s. 110). Det er viktig å vite at en sans kan overskygge andre, for eksempel at lukt, smak og følelser kan forstyrre det man synes man ser.

Tolketrening. Når vi observerer, starter vi ofte med å beskrive observasjonen nøkternt og presist, før vi tolker hva den kan bety. Studentene må trene på forskjellen på 


\section{F. O. Bakke E F. Lindstøl}

og samspillet mellom det å observere og det å tolke. Gjennom å trene blir studentene bevisst på hvordan egne erfaringer, fordommer og forkunnskaper kan virke inn på hvordan vi forstår det vi sanser (Germeten \& Bakke, 2013, s. 113). En feiloppfatning kan få stor betydning for hvordan man forstår, kommuniserer med og vurderer elever. Observasjon som er utført og tolket sammen med andre, kan gi et bredere og mer flerstemmig utgangpunkt for refleksjon og korrigering (Gjøsund \& Huseby, 2017, s. 14-15). Studentene må erfare hvordan ulike teoretiske perspektiver, f.eks. knyttet til språk, makt, elevsyn og læringssyn, kan virke inn på observasjon og tolkning (Germeten \& Bakke, 2013 s. 110).

Observasjon som metode. Dette kan forklares som en systematisk framgangsmåte for å anvende sanser til å hente inn observasjonsdata (Gjøsund \& Huseby, 2017, s. 46). Noen ganger tas det i bruk ressurser, som skjema, protokoller eller manualer. Andre ganger ønsker man en mer åpen tilnærming, der kategorier/strukturer ikke er bestemt på forhånd (Gjøsund \& Huseby, 2017, s. 47). Når vi observerer, legger vi først og fremst vekt på handlinger, det vil si hva elever og lærere gjør (Postholm \& Jacobsen, 2011 , s. 50). Studentene skal trene på å planlegge, dokumentere og formidle observasjoner til andre og bruke verktøy til å overføre observasjoner til muntlige/skriftlige tekster (Postholm \& Jacobsen, 2011, s. 50-51). De skal, ifølge styringsdokumenter, innvies i observasjon som en systematisk fremgangsmåte for datainnsamling allerede første året (Germeten \& Bakke, 2013, s. 111).

Samlet kan man si at det står noe om hva studentene skal trene på når de skal arbeide med observasjon, som sanse- og tolketrening, men det står ikke hvordan ferdighetene kan trenes. Det er dessuten få beskrivelser av hvordan man kan undervise i observasjon.

\section{Fiksjonalisering og dramaturgiske innganger}

Fiksjonalisering er en evne mennesker har til å forestille seg noe/noen i for- eller framtid. (Gladsø et al., 2015, s. 182). Fiksjonalisering handler videre om å forstå virkeligheten som noe iscenesatt og formgitt i stedet for å opprettholde grenser mellom kunst/ikke kunst, fiksjon og virkelighet: "we presume that 'the real' is created rather than as a referential reality" (Knudsen \& Krøgholt, 2019, s. 38). Fiksjonalisering har ikke som formål å imitere eller beskrive verden: «It does not describe the world as it is, but rather a potential non-perplexing or exaggerated kind of world» (Knudsen \& Krøgholt, 2019, s. 40). Fiksjonalisering kan ikke avgrenses til bestemt sjanger, stil, form eller metode, men kan brukes til å oppnå bestemte mål eller effekter (Walsh, 2007, s. 44). Om og på hvilke måter noe oppfattes som fiksjonalisering avgjøres av både sender og mottaker.

I undervisning kan fiksjonalisering komme til uttrykk når et faglig innhold settes $\mathrm{i}$ spill i klasserommet. Det kan handle om hvordan læreren planlegger og gjennomfører et faglig innhold, f.eks. utforming og bruk av læringsressurser og uttrykksformer. Lærerens fiksjonaliseringsarbeid har som formål å bevege, påvirke, berøre, utfordre og skape ulike former for læring uten å være bundet til én bestemt metode, stil, 
arbeidsform eller dramaturgi. Fiksjonalisering handler både om hvordan lærerskapte hendelser gir form til fantasien, men også om hvordan fiksjonaliseringen fullføres av den som "mottar» fiksjonen (Gladsø et al., 2005, s. 183). Det betyr at studenter har en aktiv rolle i fiksjonaliseringen - de er både mottakere og medskapere. Eksperimentering med ulike former for fiksjonalisering kan åpne for å utforske undervisningskvaliteter på tvers av form, stil eller sjanger: "The rhetoric of fictionality is brought into play whenever a narrative is offered or taken as a fiction, regardless of issues, of form, style or reference» (Walsh, 2007, s. 44). Det betyr at å eksperimentere med ulike former for fiksjonalisering kan vitalisere undervisning på tvers av faggrenser og praksiser (Knudsen \& Krøgholt, 2019, s. 38).

I dramaturgiske studier av undervisning eksperimenterer man med ulike former for fiksjonalisering og undersøker hvordan fiksjonaliseringens uttrykk kan bidra til kommunikasjon og interaksjon mellom studenter, lærer og det faglige innholdet (Knudsen \& Krøgholt, 2019, s. 38). I denne studien har vi konsentrert oss om hvordan lærerutdannere prøver ut ulike former for fiksjonalisering for å iscenesette et faglig innhold som handler om å observere og observasjon som metode.

I dramaturgisk teori er det utviklet fire dramaturgiske innganger som kan beskrive og forklare ulike former for fiksjonalisering: tid, rom, kropp og tekst (Gladsø et al., 2015, s. 192). Disse inngangene tilbyr en mer nyansert linse for dramaturgiske analyser av undervisning. Inngangene ble opprinnelig benyttet for å analysere teaterprosesser og lek, men er også adaptert til didaktiske kontekster (Øfsti, 2014; A.-L. Østern, 2014a, 2014b; T. P. Østern \& Engelsrud, 2014). På ulike måter viser adapsjonene hvordan fiksjonalisering kan komme til uttrykk i undervisning.

Tekst handler om dramaturgiens hva, altså det innholdet/temaet som lærerutdanneren ønsker å formidle (Gladsø et al., 2015, s. 197; A.-L. Østern, 2014a, s. 171). Selv om det faglige innholdet i GLU er styrt av emneplaner, læringsutbyttebeskrivelser og pensumlitteratur, handler fiksjonalisering av tekst alltid om å tilpasse, utfordre, utvide og begrense teksten gjennom f.eks. valg av ressurser, metoder, materiell og uttrykksformer. Teksten skapes i samspill mellom lærerutdanner og studenter.

Tid inkluderer både reell tid og fiksjonell tid (Gladsø et al., 2015, s.192; A.-L. Østern, 2014a, s. 171). Reell tid handler om hvor mye tid som brukes og fordeles mellom faser og hendelser i undervisningen. Fiksjonell tid er et begrep for hvordan tiden utnyttes som et virkemiddel, som f.eks. hvordan tempo, flyt, rytme og bruk av pauser bidrar til interaksjon og spenning mellom innhold og formelementer i undervisningen (T. P. Østern \& Engelsrud, 2014, s. 80). Den fiksjonelle tiden kan brukes til å avgrense, gjenta, fortette og utvide teksten. Både bruk og opplevelse av tid er knyttet til kropp, sanser og forestillingsevne.

Rom kan brukes både fiktivt og som en fysisk ramme (Gladsø et al., 2015, s. 192; Øfsti, 2014; A.-L. Østern 2014a, s. 171). Det dreier seg om hvor undervisningen utspiller seg og hvilken betydning lokaliteten har for fysisk og organisatorisk bruk. Det fysiske rommet har noe å si for hvordan deltakerne handler og interagerer. I rommet ligger muligheter og begrensninger, forventninger og tolkningsmuligheter. Det 


\section{F. O. Bakke \& F. Lindstøl}

fiktive rommet har betydning for hvordan teksten, kroppen og tiden fiksjonaliseres (T. P. Østern \& Engelsrud, 2014).

Kropp brukes til å formidle og uttrykke teksten (Gladsø et al., 2015, s. 195; A.-L. Østern, 2014a, s. 171). Bevegelse, forflytning, bruk av rom, gester, blikk og stemme har betydning for hvordan teksten og tiden kommer til uttrykk (Knudsen \& Østern, 2015; T. P. Østern \& Engelsrud, 2014). Noen ganger er fiksjonaliseringen tydelig, som når læreren spiller en rolle eller forteller på måter som markerer et brudd med lærerens hverdagskropp. Andre ganger kan signaler for spill / ikke spill eller virkelighet/fiksjon være mer skjult (Gladsø et al., 2015, s. 195), som når læreren modellerer, demonstrerer, instruerer eller simulerer.

\section{Design og metode}

En bærende idé for dramaturgiske studier er å forbinde handling, iscenesettelse og teori - å gjøre, analysere og reflektere (Lehmann 1996; Szatkowski, 1989). I denne studien forsøker vi nettopp å knytte handling og refleksjon sammen ved å ta i bruk et profesjonsverksted, som er en etablert arena for undervisning og forskning ved et universitet i Norge (Lindstøl, 2018; Lindstøl et al., 2015; Meld. St. 16 (2016-2017), s. 50). Profesjonsverkstedet er både et fysisk rom og en arena for å utvikle og utforske studentaktive læringsformer og dramaturgier i didaktiske kontekster. I denne studien ser vi på gjennomføringen, altså undervisningen satt i spill.

Studien karakteriseres som praksisledet forskning, fordi designet sentreres rundt undervisning der lærerutdannere både underviser og forsker (Cochran-Smith et al., 2019; Knudsen 2018; T. P. Østern, 2017). Videre er dette en dramaturgisk studie fordi vi benytter dramaturgi både som teori og analysemåte, men også som inspirasjon til å komponere praktiske hendelser i klasserommet. I dramaturgiske studier genereres ofte et emprisk materiale som inkluderer flere språkformer og dramaturgiske innganger som tegn på mening, som f.eks. rom, tid, kropp og tekst (Haseman, 2006, s. 103; Knudsen, 2018).

Undervisningen er gjennomført og filmet én uke før første observasjonspraksis i GLU, i to studentgrupper: 1.-7. og 5.-10. Primærdata er videoopptak av 12 timer undervisning, samt feltnotater fra to lærerutdannere som vekslet mellom å undervise og observere. Forløpet er filmet med to kamera, og det er transkribert og visualisert i tidslinjer som viser forløpets faser og hendelser (se figur 1). Under er en oversikt over datamaterialet:

Tabell 1. Oversikt over datamateriale

\begin{tabular}{lll}
\hline Data & Omfang & Studenter/lærere \\
\hline Videodata & 12 timer & 50 studenter, to grupper \\
& & 2 lærerutdannere \\
\hline Feltnotater & 12 timer & Fra deltakende observasjon
\end{tabular}


Fordi vi som lærerutdannere både underviste og forsket i studien, har vi hatt en insiderposisjon. En insider er «en person som på grunn av sin privilegerte posisjon innehar - eller antas å inneha - en kunnskap som andre ikke har» (Kvernbekk, 2005, s. 18). En slik posisjon er etablert og anerkjent innenfor dramaturgiske studier (Lehmann, 1996; Szatkowski, 1989). Imidlertid kan insider-perspektivet by på utfordringer, særlig på grunn av det asymmetriske kunnskapsforholdet mellom lærerutdannere og studenter. En fare er at studentene oppfører seg slik de tror lærerutdannere og forskeren ønsker at de skal (Fangen, 2011, s. 73). En annen utfordring er at forskeren har for liten avstand til datamaterialet eller i for stor grad forsvarer egne valg og praksiser. Dette veier vi opp for ved å presisere at dette er et utforskende og praksisledet prosjekt, der vi eksperimenterer med ulike former for fiksjonalisering. Vi har også viet stor plass til å gjøre transparente dramaturgiske analyser, og framvise data som gir en oversikt over forløpets dramaturgi (vedlegg 1 \& 2). Studien er meldt inn og godkjent av NSD, og studentene har samtykket.

\section{Dramaturgiske analyser}

Innenfor klasseromforskning er det en viktig epistemologisk distinksjon å skille mellom det lærere gjør og det de sier at de gjør (Boyd et al., 2009, s. 6; Klette, 2018). Innenfor det dramaturgiske forskningsfeltet har man også etablert et slikt analytisk skille mellom planlegging, gjennomføring og resepsjon av undervisning (Allern, 2003; 2010, s. 98; Szatkowski, 1989). Dette er uttrykt som ulike analyseområder, som har ulike data og epistemologiske implikasjoner (Kjølner \& Szatkowski, 1991, s. 122). A.-L. Østern (2014b, s. 20) har adaptert disse analyseområdene til didaktiske kontekster. Bakke \& Lindstøl (2021) har utviklet dramaturgiske analyser av hendelser, der det fokuseres på undervisning (Bakke \& Lindstøl, 2021, s. 15-16).

I denne studien startet vi med å gjøre en forløpsanalyse av transkriberte videodata og feltnotater for å identifisere dramaturgiske strukturer, det man kaller 1. orden (Szatkowski, 1989, s. 32, 2017). ${ }^{2}$ Vi identifisere hvilke faser (innledning, hoveddel og avslutning) forløpet besto av, hvor lang tid hver fase tok, og hvilke hendelser som fantes. Hendelse brukes som et synonym for en aktivitet eller handling (Barba \& Savarese, 1991, s. 68) og forklares som når og på hvilken måte noe begynner, og når og på hvilken måte noe slutter (Bakke, 2019, s. 109). Etter å identifisert hendelsene, lagde vi en skisse som ga en oversikt over deler og helheter i undervisningen.

\footnotetext{
${ }^{2}$ Vi er inspirert av Szatkowski (2011) som ut ifra et systemteoretisk ståsted beskriver forholdet mellom iakttakelser av 1. orden (hvordan man ser og forstår verden styres av egen adferd og verdier) og 2. orden (analysere av hvordan og hvorfor noen i 1 . orden ser og forstår verden). Vi benytter oss ikke av et systemteoretisk perspektiv i studiens overordnede epistemologiske forankring.
} 


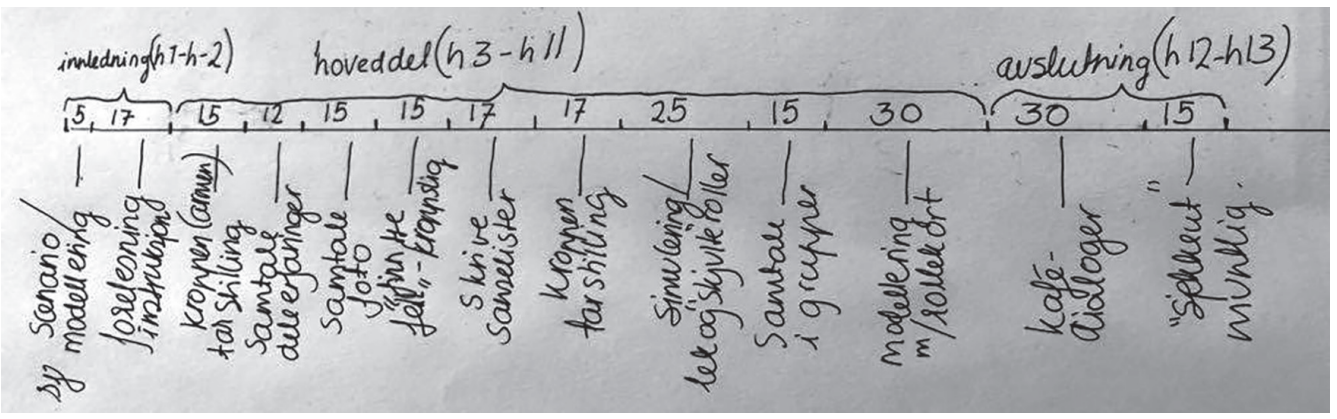

Figur 1. Skisse av undervisningsforløpet om observasjon. «H» står for hendelser og tallet viser kronologisk rekkefølge på hendelsene (f.eks «h13» er den 13. hendelsen i forløpet).

Tidslinjen illustrerer undervisningens tre faser: innledning, hoveddel og avslutning, og hvilke 13 hendelser forløpet i sin helhet består av. Forløpet varer til sammen i 198 minutter ( 4,5 undervisningstimer á 45 minutter). Den første analysen identifiserer videre hendelser med fiksjonalisering, som totalt er åtte hendelser. Disse er til utvalg i neste analyse (vedlegg 1 ).

Etter å ha fått en oversikt over forløpets 1. orden, analyserte vi forløpet igjen, rekursivt. Vi forflyttet oss til et refleksivt rom, kalt 2. orden, og analyserte tidslinjene igjen med et spesifikt blikk: Hvordan kommer fiksjonaliseringen til uttrykk i de åtte hendelsene? I analysen av enkelthendelser benytter vi oss av de fire dramaturgiske inngangene som analyseverktøy. (Vedlegg 1 gir en oversikt over hendelser og fiksjonaliseringsformer i forløpet.)

\section{Analyse av hendelser i forløpet om observasjon}

I det videre giør vi næranalyser av fire hendelser som på ulike måter setter i spill perspektiver som framheves i emneplaner og faglitteratur, sansetrening, tolketrening og observasjon som metode (se s. 3-4). Hendelsene er videre valgt fordi de viser ulike former for fiksjonalisering. Vi undersøker hendelsene ved hjelp av de fire dramaturgiske inngangene rom, kropp, tid og tekst.

Den første hendelsen, kalt scenario/modellering, er fra innledningen i forløpet.

\section{Hendelse 1: Scenario/modellering}

En student sitter ved en pult foran klassen. Hun regner matematikkoppgaver. To lærerutdannere kommenterer det studenten gjør.

Lærerutdanner A: Jeg ser en elev som har mye forskjellig på pulten sin, ark, penner, mobil og matematikkbok.

Lærerutdanner B: Jeg ser en litt rotete pult. Mobilen skulle vel vært i vesken? 
A: Jeg ser en elev som tegner en kvadrat og skriver inn tall for lengde og bredde. Hun stopper opp, det kan se ut som hun tenker.

B: Jeg tror hun er usikker på hvordan hun skal løse oppgaven, hun har ikke lest oppgaveteksten ordentlig. Er ukonsentrert.

A: Hun tegner et kryss over første utregning. Jeg ser en elev som prøver flere løsninger, tenker og fortsetter arbeidet.

B: Jeg synes hun lager et rotete oppsett, det virker som hun mangler fagkunnskap eller har problemer med å konsentrere seg.

A: Jeg ser en elev som tar seg litt i hodet, bøyer seg fremover og vipper på stolen.

B: Dette har jeg erfart mange ganger, kroppslig uro er ofte et tegn på andre ting hvis du skjønner hva jeg mener [ler].

Rommet fiksjonaliseres både som et fiktivt klasserom og et metarefleksivt rom, der to lærere beskriver og tolker elevens oppgaveløsning. Studentene kan identifisere seg med både eleven og lærerne, fordi de selv har vært elever og fordi de snart skal gjennomføre egen praksis med vekt på observasjon. Det er en spenning mellom elevens handlinger ved skolepulten og lærernes kommentarer som forsterkes gjennom fiksjonalisering av tiden, fordi alle er i samme rom på samme tid. Studentene vil kunne identifisere seg med eleven som blir utsatt for lærernes blikk og vurderingspraksis uten å selv kunne forklare eller forsvare handlinger og valg. De to lærerne veksler mellom å beskrive og tolke i en jevn rytme. Elevens tempo ligner på realtiden og påvirkes ikke av lærernes språk, som øker i tempo og intensitet. Læreren som tolker bruker gradvis kortere tid på å tenke seg om før hun ytrer seg om hvordan hun forstår elevens handlinger. Kontrasten mellom elevtempo og lærertempo antyder et vendepunkt, der det blir tydeligere signalisert at den ene lærerutdanneren fiksjonaliserer en privat og ufaglig kommentatorrolle: «Jeg tror hun er usikker på hvordan hun skal løse oppgave. Hun har ikke lest oppgaveteksten ordentlig. Er ukonsentrert.» Måten lærerkroppene skifter fra ikke-spill til spill forsterker vendepunktet, og en uprofesjonell lærerrolle blir gradvis signalisert. Læreren som beskriver eleven motsetter seg ikke kollegaens slurvete og private tolkninger. Hun framstår også som uprofesjonell i sin passivitet. Klimaks oppstår når det er tydelig at læreren som tolker bruker private fordommer som referanse for egne tolkninger: «Dette har jeg erfart mange ganger. Kroppslig uro er ofte et tegn på andre ting.» Fordi det meste av iscenesettelsen er regissert på forhånd, og studentene i liten grad kan medvirke og medskape, får fiksjonaliseringen dobbel kraft. Studentene blir påtvunget en rolle som passive observatører.

Hendelsen som vi har kalt modellering/scenario er et praktisk eksempel på hvordan lærerutdanneren kan fiksjonalisere rommet, tiden og kroppen for å iscenesette teksten som her både handler om å observere og tolke og om spenninger mellom det profesjonelle og private blikket. Fordi lærerutdannerne utforsker grensen mellom spill og ikke-spill skapes en mulighet for studentene til å ta stilling til og bli berørt av 
en situasjon der fordommer brukes som argumentasjon og vurdering. I likhet med observatørene som ikke visste om at de deltok i et gorillaeksperiment, får studentene påført en rolle som de ikke selv er klar over. Fordi erfaringen kan oppleves som ubehagelig, kan den bidra til at studentene blir mer ambivalente og kritiske til hva som er sant eller ikke. Fordi hendelsen spissformulerer utfordringer knyttet til det å sanse og tolke, kan den fungere som et anslag, en teaser, i forløpet, der observasjon som ferdighet og metode problematiseres.

\section{Hendelse 2: Skrive sanselister}

Den andre hendelsen, kalt skrive sanselister, er fra hoveddelen i forløpet:

Lærerutdanneren A: Da jeg var liten, var jeg redd for hunder. Når jeg besøkte venner la jeg merke til lukten av våt hund. Jeg ble anspent og var på vakt, jeg så etter potensielle farer i alle rom, jeg lyttet etter hundepust og bjeffing. Som voksen er jeg selv hundeeier. Jeg legger nesten ikke merke til hundelukten og opplever huset mitt som trygt og hyggelig. Hvorfor tror dere at sansingen forandret seg?

Student 1: $\quad$ Du har vent deg til det.

Student 2: $\quad$ Du kobler lukta til følelser og stemning. Og til det du ser.

Student 3: $\quad$ Du har erfart at hunder ikke er farlige.

Lærerutdanner: Dere skal forestille dere et sted dere har bodd eller vært i barndommen. Det kan være et hyggelig eller mindre hyggelig sted. Tenk at dere vandrer gjennom huset eller leiligheten. Skriv en liste med lukter og lyder i huset, som: Yttergangen - våt hund og sure fotballsko, stua - metronom og piano...

I denne hendelsen fiksjonaliseres rommet gjennom skriftlige lister som språkliggiør sanselige minner. Listene uttrykker følelser, stemninger og erindringer om barndom, oppvekst og et barndomshjem. Studentene forestiller seg steder ut ifra beskrivelser av lukter og lyder. Det skjer en jevn rytmisk veksling mellom fiksjonell tid (barndom) og realtid, der studentene reflekterer over erfaringer og fortellinger fra et sted/rom, en tid og forestiller seg barnets blikk og minner. Både det å skrive og lytte til andres tekster, kan sette i spill betydningen av sanselige og kroppslige minner og erfaringer. Tekstene fungerer som en inngang til å reflektere over hva sansing er, og hvordan sanseinntrykk har betydning for tolkning, som at lyd kan påvirke stemning, følelser og holdninger. I denne hendelsen handler teksten om flersanselige observasjoner, og hvordan en sans er knyttet til hukommelse, følelser og erfaringer, som kan virke inn på hvordan man som lærer observerer og tolker. Som gorillaeksperimentet innledninsgvis viste, kan synssansen være upålitelig. Man ser ikke alt.

Oppsummert er hendelsen å skrive sanselister et eksempel på praktisk undervisning som kan skape et flerstemmig utgangspunkt for å erfare og snakke om sansenes betydning når man observerer i klasserommet, f.eks. hvordan sanser kan berike, men også forstyrre observasjoner. 


\section{Hendelse 3: Simulering av lek og skjulte roller}

Den tredje hendelsen, kalt simulering av lek og skjulte roller, er fra hoveddelen i forløpet:

Tjue studenter skal observere, mens sju studenter har fått i oppdrag å leke sisten med «skjulte» spilleregler: Eva får aldri sisten. Arne diskuterer reglene. Trine uttrykker begeistring. Per sjekker telefonen. Lise bryter reglene. Fire av studentene som observerer har fått et skjult oppdrag som handler om å overbevise de andre om falske observasjoner, det vil si hendelser som faktisk ikke skjer under sistenleken.

Lærerutdanner: Hva observerte dere?

Observatør 1: Eva blir utestengt fra leken.

Observatør 2: Arne er en kranglete type.

Muldvarp 1: $\quad$ Lise gir sisten til alle uten at hun har den selv.

Muldvarp 2: $\quad$ Det så ut som Lars tok på Trine på en litt ekkel måte.

Muldvarp 3: $\quad$ Han Lars virker litt klein, han er mer opptatt av jenter enn av sisten.

Muldvarp 1: $\quad$ Lars tok Eva nederst på ryggen, nesten på rumpa.

Lærerutdanner: Er dere enige i det som ble sagt? Dere har formidlet hva dere så?

I denne hendelsen fiksjonaliseres rommet som to steder samtidig - som en sistenlek i klasserom og som et refleksjonsrom der observasjoner deles og diskuteres med andre. Kontraster mellom en vanlig sistenlek og de skjulte spillereglene bidrar til at studentene må skjerpe blikket for å legge merke til et komplekst samspill mellom individer og grupper. Når observasjonene skal deles og diskuteres, blir de fleste spillereglene kommentert. Observatørene har lagt merke til både ytre handlinger og mer skjulte viljer og relasjoner. I delingssekvenser formidler de falske observatørene sine usanne påstander. De har kort tid til å manipulere sine medobservatører. Med dette fiksjonaliseres et nytt rom i observatørgruppa; rommet med de «falske seerne». Det er først når lærerutdanner avslører muldvarpene at det tredje rommet blir signalisert. Flere ler, og mange uttrykker at de er sjokkerte og flaue over at de ikke sa ifra. I den første delen av hendelsen fungerer lærerutdanner som en fasilitator som organiserer og instruerer aktiviteten. Da de skjulte observatørene avsløres, blir lærerutdanneren mer tydelig fiksjonalisert - hun spiller på lag med de skjulte observatørene. Det tredje fiksjonsrommet bryter med den etablerte fiksjonskontrakten som handler om at alle observatørene hadde samme intensjon og vilje. Med dette endrer teksten innhold fra først å handle om hvordan man teknisk kan gjennomføre og formidle observasjoner sammen med andre, til så å handle om hvordan observatører påvirkes av kontekst, situasjon og andres blikk. Det samme fenomenet oppsto i gorillaeksperimentet, der flere av tilskuernes blikk ble påvirket av konvensjoner og forventninger knyttet til det som vanligvis skjer på en basketballbane.

Samlet kan vi si at i hendelsen utnyttes spillerommet mellom fiksjon og ikkefiksjon, og fiksjonaliseringen blir gradvis tydeligere signalisert. Med dette setter hendelsen i spill betydningen av hvordan og hvorfor man formidler observasjoner til andre. 


\section{Hendelse 4: Modellering med rollekort}

Den fjerde hendelsen, modellering med rollekort, er også fra hoveddelen i forløpet:

Lærerutdanneren underviser i «Draum om hausten» av Jon Fosse, tilpasset 10. trinn. Halve klassen er i rolle. Rollekortene til studentene er ukjent for læreren og utformet som korte instruksjoner som: «Du skal koble teksten til eget liv og formidle tankene dine til klassen» eller «Du er opptatt av om teksten er pensum og hva som er vurderingskriterier». Den øvrige halvdelen er observatører og bruker et observasjonsskjema.

På smarttavla vises et fotografi av en kirkegård som ligger ved åpen sjø. En lydkulisse fyller rommet: havbrus, måkeskrik og lyden av menneskestemmer. Lysbildet veksler. Musikken endres.

Lærerutdanner (i rolle som lærer L1) sier:

Student 1 (i rolle som elev):

Student 2 (i rolle som elev) rekker opp hånden:
Les replikkene. Noter raskt ned det du tenker: Hvem er det som er her? Hvor er vi? Hvorfor er vi her? Hva giør vi her? Når foregår dette? Hun vender seg mot klassen:

Jeg tenker at det handler om et hemmelig møte.

Jeg synes det er rart å ha en date på en kirkegård, jeg skjønner ikke poenget.

\section{[fiksjonen brytes]}

L1: Hva er det dere ser og hvordan tolker dere det dere ser?

S1: Læreren er veldig profesjonell.

L1: Hva betyr det?

S1: Det betyr at du tar lærerrollen seriøst. Du ser elevene. Du glemmer ikke, hvis det er noen som har rekt opp hånda så går du tilbake til det igjen. Du forbereder hva som kommer. Det er en fin oppbygging og du har liksom kontroll på klassen.

S2: Du har et fint engasjement på starten. Du er så glad og viser at du synes dette er skikkelig artig.

S3: Det virker som du kjenner elevene veldig godt. Du går bort til de som pleier å lage støy, og var føre var...

S4: Du ga ikke svar på spørsmålet med en gang, du lot elevene tenke litt og sa at vi kommer tilbake til det. Når det var noen som stilte spørsmål så sa hun «Bra spørsmål».

S5: Du beveger deg fint rundt i rommet, har overblikk.

S2: Jeg synes det var fint den måten du ordla deg på. Når det var noe bra kommenterte du det. Det er jo fokus på at man ikke skal stemple elever som veldig gode eller dårlig. Det var relevante spørsmål. Jeg synes du håndterte alle så respektfullt. Så ingen følte at de ikke kunne bidra.

Hendelsen fiksjonaliseres som et fiktivt klasserom, der lærerstudenter observerer på samme måte som de gjør i ordinær praksis. Hendelsen fremstår derfor som en kollektiv improvisasjon der fiksjonaliseringen er tydelig signalisert. Fiksjonell tid og realtid er ganske lik, selv om rytme i handlinger og samtaler framstår som noe fortettet. Det er glidende overganger mellom lærerutdannerens og lærerens kropp, mens verbalspråket er tilpasset 10. trinn. Fiksjonaliseringen signaliseres også tydelig fordi studentene bruker det samme observasjonsskjemaet som de skal bruke i praksis (se vedlegg 3). 
Elevkroppene fiksjonaliseres som handlinger (skrive, giøre oppgaver, forstyrre, rekke opp hånda, virke uinteressert) og språk (spørre, kommentere, svare på ulike måter). I tillegg fiksjonaliseres en undervisningssituasjon med elever som har ulik motivasjon og vilje. Man kan si at studentene både observerer en fiktiv lærers undervisning og en lærerutdanneres undervisning om det å undervise. Lærerutdanneren iscenesetter seg selv som underviser, leder, improvisatør og dramaturg.

Oppsummert kan vi si at teksten både handler om observasjon som metode og om lærerutdannerens lærerrolle og undervisningsferdigheter knyttet til et forløp i norsk om dramatikeren Fosse. I hendelsen iscenesettes spenninger mellom studentene handlinger (i roller som elever) og lærerutdannerens ferdigheter (i rollen som læringsleder og improvisatør). Studentene får trening i å bruke observasjonsverktøy og formidle observasjoner til andre.

Samlet viser de dramaturgiske analysene av de tre hendelsene hvordan ulike former for fiksjonalisering kan brukes i en undervisning som handler om å observere. Vi viser eksempler på hvordan fiksjonalisering av rom, tid, kropp og tekst kan ha flere formål: sansetrening, tolketrening og observasjon som metode. Gjennom å eksperimentere med fiksjonell og reell bruk av rom, tid og kropp, iscenesettes spenninger mellom det profesjonelle og private blikket.

I det videre diskuterer vi et dramaturgisk mulighetsrom for lærerutdannere som ønsker å utvikle og forske på undervisning.

\section{Nyanser av fiksjonalisering utfordrer og berører}

I studien viser vi eksempler på hvordan eksperimentering med fiksjonalisering kan bidra til praktisk trening i observasjon og innvielse i observasjon som metode. Analysen viser at undervisning i observasjon har flere likhetstrekk med simulering, fordi lærerutdannerne og studenter fiksjonaliserer situasjoner og roller som imiterer klasserom og skole (Dotger, 2011). Likevel bryter også flere av hendelsene med prinsipper for simulering, fordi det i undervisningen eksperimenteres med å formgi og iscenesette grenser og nyanser mellom fiksjon og ikke-fiksjon, spill og ikke-spill. Fiksjonskontrakten iscenesettes og reforhandles, i og på tvers av hendelsene og bidrar derfor til å uttrykke det Knudsen og Krøgholt kaller en "potential non-perplexing or exaggerated kind of world» $(2019$, s. 40). Målet er ikke å imitere eller gjenskape klasserommets estetikk, men å iscenesette for å berøre og påvirke studentene. Gjennom fiksjonalisering blir studentene nærmest påført et ubehag som kan oppstå når fordommer, private agendaer og unyanserte beskrivelser formidles av en lærer som forventes å være profesjonell. Med dette problematiseres hvordan og hvorfor en profesjonell lærer formidler observasjoner til andre. Det viser at det er lett å bli påvirket av andres språk eller blikk for å oppnå anerkjennelse $i$ et felleskap.

Oppsummert kan vi si at ulike former for fiksjonalisering kan være godt egnet til å trene og innvie studentene i observasjon, men også til å utforske etiske, metodologiske 


\section{F. O. Bakke \& F. Lindstøl}

og epistemologiske problemstillinger knyttet til observasjonsrollen og observasjon som metode (Germeten \& Bakke, 2013, s. 111; Gjøsund \& Huseby, 2017, s. 47). Studien er dermed et praktisk bidrag til hvordan man kan arbeide med ulike former for fiksjonalisering i lærerutdanningen. Fordi fiksjonalisering ser ut til å ha stor kraft og kan brukes til å berøre og involvere studentene, kan erfaringene fra denne studien overføres til andre emner og praktiske ferdigheter i lærerutdanningen; som veiledning, læringsledelse, konfliktløsning, muntlig formidling eller deltrening på komposisjon av et forløp, som f.eks. oppstart av en time. Disse funnene kan ha noen implikasjoner for hvordan man underviser i observasjon, som drøftes i det følgende.

\section{Observasjonsundervisningens dramaturgi - samspill mellom deler og helheter}

Den dramaturgiske analysen av undervisningsforløpet (figur 1) viser at de tre observasjonsferdighetene gjentas og remedieres flere ganger og på ulike måter i forløpet. I analysen av undervisningsforløpets dramaturgi, identifiserer vi flere dramaturgiske grep som ble benyttet i undervisning om observasjon. Disse kan oppsummeres i følgende punkter:

- Fra det enkle til det komplekse. I den første hendelsen, kalt scenario/modellering, trener studentene på enkle, isolerte ferdigheter, som å sanse eller å tolke. Den siste hendelsen er mer kompleks, fordi den krever at studentene kombinerer sansing, tolkning og observasjon som metode i klasserommet.

- Fra det kjente til det ukjente. I den første hendelsen kan studentene identifisere seg med elevrollen og minner som er kjent fra egen skolehverdag og oppvekst. De tar i bruk et hverdagsspråk. Videre i forløpet fokuseres det mer på å identifisere seg med andre, på ukjente elevroller og rollen som profesjonell lærer. I tillegg inkluderes begreper og teori knyttet til observasjon som vitenskapelig metode.

- Veksling mellom innlevelse og refleksjon. Gjennom forløpet veksles det mellom å gjøre, oppleve, erfare og identifisere seg med ulike situasjoner og roller og å diskutere i helklassesamtale. For eksempel i hendelse 4, som vi har kalt modellering med rollekort, bruker studentene erfaringer fra å delta og observere fiktiv undervisning til å diskutere lærerutdannerens læringsledelse, språk og tilpasning.

- Fra en lukket til en mer åpen dramaturgi. I forløpet ser vi at lærerutdanneren gradvis åpner mer opp for at studentene kan medvirke, f.eks. i hendelsen modellering med rollekort, der studentene både deltar og diskuterer modelleringen. I starten av forløpet (scenario/modellering) framstår lærerutdannerens regi som lukket med få muligheter for studentene til å medvirke, mens etterhvert åpnes det opp for at studentenes selv er medskapere $\mathrm{i}$ innhold og form.

Nedenfor har vi laget en visualisering av dramaturgiske valg som ble benyttet i undervisning om observasjon: 


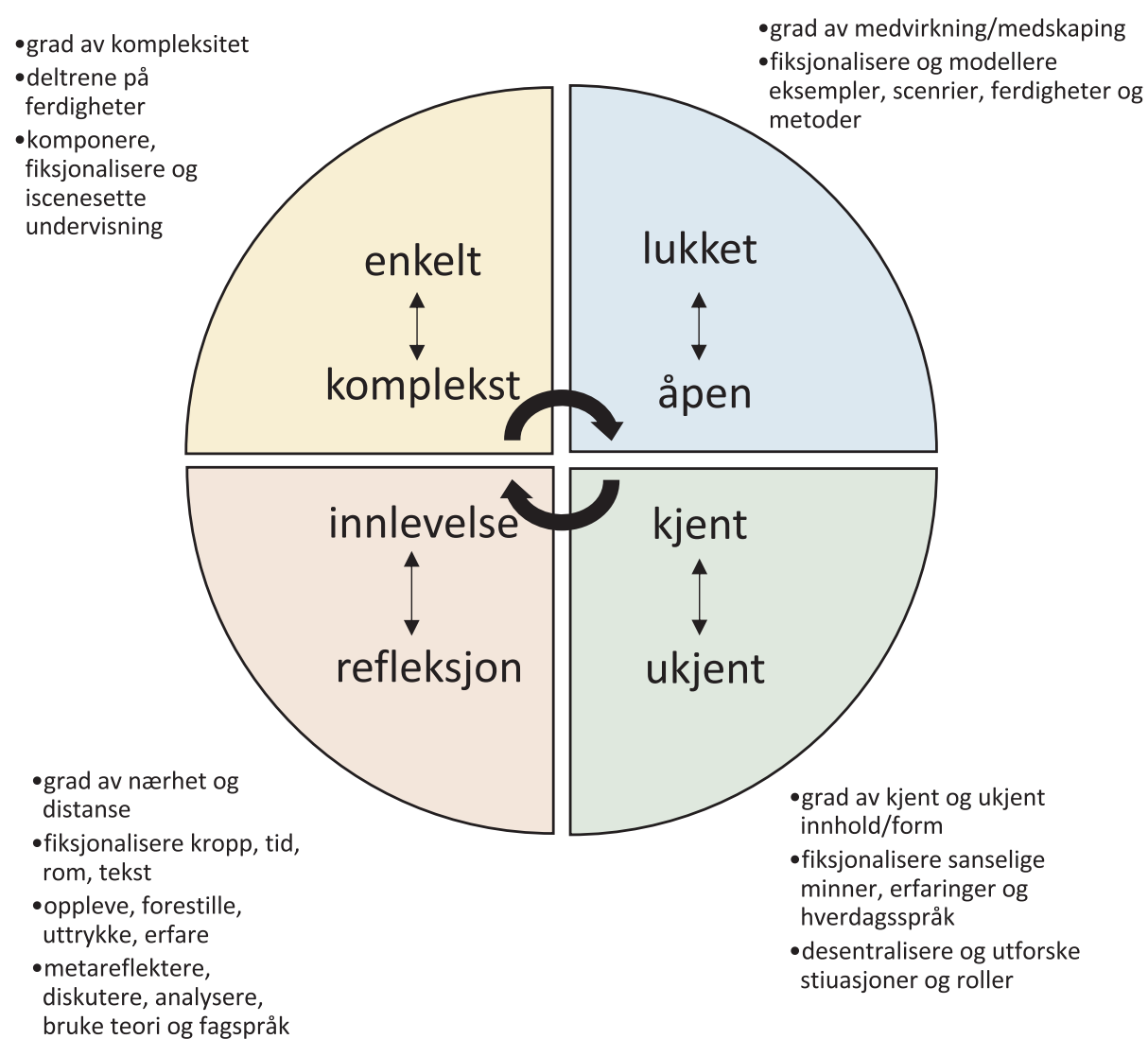

Figur 2. En visualisering av dramaturgiske valg som ble benyttet i undervisning om observasjon. De dramaturgiske valgene åpner for å tilnærme seg arbeid med observasjon på ulike måter og med ulike nivå av kompleksitet. Det skapes rom for at studentene kan medvirke og medskape slik at sansing og tolkning kan utfordres, slik som det etterspørres i faglitteraturen og emneplaner.

Oppsummert kan vi si at dramaturgiske analyser av forløpet synliggiør en veksling mellom ulike former for fiksjonalisering og refleksjoner i helklasse. Det betyr at erfaringene som studentene får gjennom fiksjonaliseringsprosessene skaper et kollektivt utgangspunkt for å diskutere fagdidaktiske, metodologiske, etiske og pedagogiske problemstillinger. Komposisjonen gir studentene muligheter til å identifisere seg med ulike (og ofte motstridende) perspektiv og roller, som virker sammen når man skal planlegge og gjennomføre observasjoner i klasserommet. Komposisjonen bidrar til at flere betydningslag kan oppstå, slik at studentene kan ta stilling, forklare og argumentere for eget ståsted. Studentene kan også parafrasere over ulike forklaringer og eksempler og se sammenhenger. Det gir tolkningsmuligheter, og det kan utfordre sansing og tolkning, slik som det etterspørres i faglitteraturen og emneplaner. Oppsummert er studien et praktisk bidrag til lærerutdannere eller andre undervisere som skal undervise i observasjon som ferdighet og metode. 


\section{F. O. Bakke \& F. Lindstøl}

\section{En gorilla (og kanskje en elefant) i klasserommet - lærerutdanneren som dramaturg}

Selv om det i norsk lærerutdanninng arbeides systematisk med undervisningskvalitet, fins det også noen vekstpunkt, eller gorillaer i rommet, som vi ikke ser. Den gorillaen, som kanskje heller er en elefant, i rommet - og som vi ikke snakker om - handler om hvorvidt man i lærerutdanningen i liten grad har prioritert systematisk og fagovergripende arbeid med praktisk undervisning (Janssen et al., 2015, s. 139-144; Jenset et al., 2018; Ulvik \& Smith, 2016, s. 65). Fordi lærerutdannere har et dobbelt oppdrag i form av å undervise om det å undervise, får måter vi underviser på signifikant verdi - både innhold og form blir en del av budskapet (Ulvik \& Smith, 2016, s. 63). Så lenge lærerutdannere snakker om praksiser og læringsteorier som de selv ikke modellerer, er det lite sannsynlig at det vil skje en utvikling av undervisningskvalitet. Det er derfor et råd at det arbeides systematisk og praktisk med undervisning i tett samarbeid med studenter og praksislærere (Lillejord \& Børte, 2017, s. 2-3).

I denne studien har vi forsøkt å gjøre det som den ovennevnte forskningslitteraturen etterspør. Vi har samarbeidet på tvers av fag, modellert, komponert og prøvd ut undervisning som inkluderer praktiske ferdigheter. Vi har forsket på egen og hverandres undervisning. Ikke minst har vi utsatt oss selv og studentene for risiko, fordi det ikke fins én metode eller én praksis vi kan imitere eller bygge på. Gjennom praktisk utprøving og dramaturgiske analyser peker vi på hvordan fiksjonalisering kan bringes inn $\mathrm{i}$ undervisning om og med observasjon. Studien er derfor et konkret bidrag som lærerutdannere kan bringe med inn i deres undervisning om å undervise. Vi mener selv at vi har sett nærmere på minst én gorilla - som vi oppdaget i egne klasserom.

\section{Forfatteromtale}

Fride Lindstøl er førsteamanuensis og merittert underviser ved Universitetet i Sørøst-Norge. Hun underviser i drama- og teaterfag, pedagogikk, dramaturgi og estetiske læreprosesser. Hun forsker på temaer som kunstpedagogikk, litteraturdidaktikk, lærerutdanning og dramaturgi i didaktiske kontekster. Hun har publisert flere vitenskapelige tekster, læremidler, skjønnlitterære tekster og har vært med på å skape flere kunst- og teaterproduksjoner som involverer barn og ungdom. Hun underviser og forsker på undervisning i et profesjonsverksted, "et læringslaboratorium», sammen med Jannike Ohrem Bakke og lærerutdannere, studenter og praksislærere som er tilknyttet USN.

Jannike Ohrem Bakke er førsteamanuensis og merittert underviser ved Universitetet i Sørøst-Norge. Hun underviser først og fremst i grunnleggende ferdigheter og litteraturdidaktikk i lærerutdanningen og forsker på temaer som skriving, læringsressurser, dramaturgi og litteraturdidaktikk. Hun har bidratt i flere lærebøker for grunnog videregående skole, skrevet vitenskapelige tekster, deriblant om dramaturgi i en didaktisk kontekst og skrevet en doktorgrad om iscenesettelse av skriveoppgaver. 
Hun underviser og forsker på undervisning i et profesjonsverksted, "et læringslaboratorium", sammen med Fride Lindstøl og lærerutdannere, studenter og praksislærere som er tilknyttet USN.

\section{Referanser}

Allern, T.-H. (2003). Drama og erkjennelse: En undersøkelse av forholdet mellom dramaturgi og epistemologi $i$ drama og dramapedagogikk [Doktoravhandling]. Norges teknisk-naturvitenskapelige universitet.

Allern, T.-H. (2010). Dramaturgy in teaching and learning. I A.-L. Østern, M. Björkgren \& B. Snickars-von Wright (Red.), Drama in three movements: A Ulyssean encounter (s. 95-111). Åbo Akademi University.

Bakke, J. O. (2019). Skriveforløpets dramaturgi: A iscenesette et skriveoppdrag. En kvalitativ studie av skriveundervisning $i$ norsk, samfunnsfag og naturfag på 7. trinn, gjennomført $i$ Normprosjektet [Doktoravhandling, Universitetet $\mathrm{i}$ Sørøst-Norge]. USN Open Archive. http://hdl.handle.net/11250/2582386

Bakke, J. O. \& Lindstøl, F. (2021). Chasing fleeing animals - on the dramaturgical method and the dramaturgical analysis of teaching. Research in drama education: The journal of applied theatre an performance, 26(2), 283-299. https://doi.org/10.1080/13569783.2021.1885370

Barba, E. \& Savarese, N. (1991). A dictionary of theatre anthropology: The secret art of the performer. Routledge.

Bjørndal, C. R. P. (2011). Det vurderende øyet. Observasjon, vurdering og utvikling $i$ undervisning og veiledning. Gyldendal Akademisk.

Boyd, D. J., Grossman, P. L., Lankford, H., Loeb, S. \& Wyckoff, J. (2009). Teacher preparation and student achievement. Educational Evaluation and Policy Analysis, 31(4), 416-440. https://doi.org/10.3102/016237370935312

Cochran-Smith, M., Grudnoff, L., Orland-Barak, L. \& Smith, K. (2019). Educating teacher educators: International perspectives. The New Educator, 16(1), 5-24. https://doi.org/10.1080/1547688X.2019.1670309

Darling-Hammond, L. (2006). Constructing $21^{\text {st }}$-century teacher education. Fournal of Teacher Education, 57(3), 300-314. https://doi.org/10.1177/0022487105285962

Dotger, B. (2011). From know how to do now: Instructional applications of simulated interactions within teacher education. Teacher Education and Practice, 24(2), 132-148.

Germeten, S. \& Bakke, J. (2013) Observasjon: Å innta klasserommet med egne sanser. I M. Brekke \& S. Tiller (Red.), Lereren som forsker. Innføring $i$ forskningsarbeid $i$ skolen (s. 109-123). Universitetsforlaget.

Gladsø, S., Gjervan, E. K., Hovik, L. \& Skagen, A. (2015). Dramaturgi: Forestillinger om teater. Universitetsforlaget.

Gjøsund, P. \& Huseby, R. (2017). Eleven i fokus. Observasjonsarbeid i skolen. Cappelen Damm Akademisk.

Grossman, P., Hammerness, K. \& McDonald, M. (2009). Redefining teaching, re-imagining teacher education. Theory and Practice, 15(2), 273-289. https://doi.org/10.1080/13540600902875340

Haseman, B. (2006). A manifesto for performative research. Media International Australia, 118(1), $98-106$. https://doi.org/10.1177/1329878X0611800113

Hustvedt, S. (2013). Livet, tanken, blikket. Aschehoug.

Jacobsen, D. I. \& Postholm, M. D. (2011). Lereren med forskerblikk. Innføring $i$ vitenskapelig metode for lcererstudenter. Høyskoleforlaget.

Janssen, F., Grossman, P. \& Westbroek, H. (2015). Facilitating decomposition and recomposition in practicebased teacher education: The power of modularity. Teaching and Teacher Education, 51, 137-146. https:// doi.org/10.1016/j.tate.2015.06.009

Jenset, I. S., Klette, K. \& Hammerness, K. (2018). Grounding teacher education in practice around the world: An examination of teacher education coursework in teacher education programs in Finland, Norway, and the United States. Fournal of Teacher Education 69(2), 184-197. https://doi.org/10.1177/0022487117728248

Jong, T. D., Lane, J. \& Sharp, S. (2012). The efficacy of simulation as a pedagogy in facilitating pre-service teachers' learning about emotional self-regulation and its relevance to the teaching profession. Australian Fournal of Teacher Education, 37(3), 33-43. https://doi.org/10.14221/ajte.2012v37n3.6

Kjølner, T. \& Szatkowski, J. (1991). Dramaturgisk analyse - et arbeidsredskap for ikke-naive instruktører. I H. Reistad (Red.), Regikunst (s. 122-132). Tell forlag.

Klette, K. (2018). A new generation classroom studies. I C. Osbeck, Å. Ingerman \& S. Claesson (Red.), Didactic classroom studies: A potential research direction (s. 225-242). Nordic Academic Press. https://doi. org/10.21525/kriterium.14

Knudsen, K. N. (2018). Forskeren som dramaturg. Dramaturgi som refleksiv metodologi. fournal for Research in Arts and Sports Education, 2(1), 39-52. https://doi.org/10.23865/jased.v2.1032 


\section{F. O. Bakke \& F. Lindstøl}

Knudsen, K. N. \& Krøgholt, I. (2019). Revitalizing drama in education through fictionalization - a performative approach. I A.-L. Østern \& K. N. Knudsen (Red.), Performative approaches in arts education:Artful teaching, learning and research (s. 38-55). Routledge.

Knudsen, K. N. \& Østern, T. P. (2015). Rektor, kend din krop - med kroppen som et spejlbillede. I A. B. Emstad \& E. Angelo (Red.), Ledelse for lering $i$ mulighetenes skole. Skoleledelse $i$ skjceringsfeltet mellom allmenndanning og talentutvikling (s. 84-89). Cappelen Damm Akademisk.

Kvernbekk, T. (2005). Pedagogisk teoridannelse: Insidere, teoriformer og praksis. Fagbokforlaget.

Kunnskapsdepartementet. (2016a). Forskrift om rammeplan for grunnskolelcererutdanningen for trinn 5.-10 (FOR-2016-06-07-861). Lovdata. https://lovdata.no/LTI/forskrift/2016-06-07-861

Kunnskapsdepartementet. (2016b). Forskrift om rammeplan for grunnskolelcererutdanningen for trinn 1.-7 (FOR-2016-06-07-860). Lovdata. https://lovdata.no/forskrift/2016-06-07-860

Lehmann, N. (1996). Dekonstruktion og dramaturgi. Aarhus Universitetsforlag.

Lillejord, S. \& Børte, K. (2017). Lcererutdanning som profesjonsutdanning - forutsetninger og prinsipper fra forskning. Et kunnskapsgrunnlag. Forskningsrådet.

Lindstøl, F. (2018). Mellom risiko og kontroll - dramaturgiske perspektiverlarerutdanneres undervisning [Doktoravhandling, Universitetet i Sørøst-Norge]. USN Open Archive. http://hdl.handle.net/11250/2564049

Lindstøl, F., Bakke, J. O. \& Moe, M. (2015). As if. Om profesjonsverksted i GLU. I I. E. K. Høihilder \& O. A. Gulbrandsen (Red.), Pedagogikk og elevkunnskap i grunnskolelcererutdanningen: PEL $i$ GLU (s. 305-314). Gyldendal Akademisk.

Meld. St. (2016-2017). Kultur for kvalitet $i$ høyere utdanning. Kunnskapsdepartementet. https://www.regjeringen. no/no/dokumenter/meld.-st.-16-20162017/id2536007/

Molander, A. \& Terum, L. I. (2008). Profesjonsstudier - en introduksjon. I A. Molander \& L. I. Terum (Red.), Profesjonsstudier (s. 13-29). Universitetsforlaget.

Nasjonalt råd for lærerutdanning. (2017a). Nasjonale retningslinjer for grunnskolelcererutdanning trinn 5-10. https://www.uhr.no/_f/p1/i29343138-8b41-4366-a291-f45bc1e5ed85/godkjent_5_10_010916.pdf

Nasjonalt råd for lærerutdanning. (2017b). Nasjonale retningslinjer for grunnskolelcererutdanning trinn 1-7. https:// www.uhr.no/_f/p1/i2a5b28d8-ae69-4ff0-adf3-2048cdfae6af/godkjent_1_7_010916.pdf

Rasmussen, B. (2013). Teater som danning - i pragmatisk-estetiske rammer. I K. M. Heggstad, S. A. Eriksson \& B. Rasmussen (Red.), Teater som danning (s. 21-37). Fagbokforlaget.

Szatkowski, J. (1989). Dramaturgiske modeller - om dramaturgisk tekstanalyse. I E. E. Christoffersen, T. Kjølner \& J. Szatkowski (Red.), Dramaturgisk analyse. En antologi (s. 9-92). Universitetet i Århus, Institutt for dramaturgi.

Szatkowski, J. (2011). Person og rolle. I J. Szatkowski, E. E. Christoffersen \& T. R. Nielsen (Red.), Peripeti. Performative former (s. 11-137). Afdeling for Dramaturgi, Aarhus Universitet.

Ulvik, M. \& Smith, K. (2016). Å undervise om å undervise: Lærerutdanneres kompetanse sett fra deres eget og fra lærerstudenters perspektiv. Uniped, 39(1), 61-77.

Universitetet i Sørøst-Norge. (2019). Praksishåndbok. MGLU 1.-7. og 5.-10. trinn. https://www.usn.no/getfile. php/13575821-1601816816/usn.no/studier/Praksis/Lærerutdanning/Campus\%20-\%20Praksishåndbok $\% 20$ for\%20ny\%20master\%20grunnskolelærerutdanning.pdf

Walsh, R. (2007). The rhetoric of fictionality: Narrative theory and the idea of fiction. Ohio State University.

Øfsti, R. (2014). Rommet og undervisninga - læraren som scenograf. I A.-L. Østern (Red.), Dramaturgi $i$ didaktisk kontekst (s. 87-121). Fagbokforlaget.

Østern, A.-L. (2014a). Det uavsluttede. I A.-L. Østern (Red.), Dramaturgi i didaktisk kontekst (s. 169-174). Fagbokforlaget.

Østern, A.-L. (2014b). Å tenke som en dramaturg i undervisningen. I A.-L. Østern (Red.), Dramaturgi i didaktisk kontekst (s. 19-37). Fagbokforlaget.

Østern, T. P. \& Engelsrud, G. (2014). Kontakt, kommunikasjon og ledelse som lærerkropp. I A.-L. Østern (Red.), Dramaturgi i didaktisk kontekst (s. 67-87). Fagbokforlaget.

Østern, T. P. (2017). Å forske med kunsten som metodologisk praksis med aesthesis som mandat. fournal for Research in Arts and Sports Education, 1(5), 7-27. https://doi.org/10.23865/jased.v1.982

Østrem, S. (2009). Lærerutdanningens bidrag i læreres kunnskapsutvikling. Nordic Studies in Education, 29(4), 369-383. 